\title{
Níveis de Carboidratos em Folhas de Videiras Infetadas por Grapevine virus A, Grapevine virus B e Grapevine leafroll-associated virus 3
}

\author{
Henrique P. Santos ${ }^{1}$, Marco A. S. Tiné2 \& Thor V. M. Fajardo ${ }^{1}$ \\ 'Embrapa Uva e Vinho, Cx. Postal 130, CEP 95700-000, Bento Gonçalves, RS, e-mail: henrique@cnpuv.embrapa.br; \\ ${ }^{2}$ Seção de Fisiologia e Bioquímica de Plantas, Instituto de Botânica, São Paulo, SP
}

(Aceito para publicação em 03/06/2004)

Autor para correspondência: Henrique P. Santos

\begin{abstract}
Carbohydrate levels in grapevine leaves infected with Grapevine virus A, Grapevine virus $B$ and Grapevine leafroll-associated virus 3

The carbohydrate levels of grapevine (Vitis spp.) leaves were strong influenced by Grapevine virus $A$ (GVA), Grapevine virus B (GVB) and Grapevine leafroll-associated virus 3 (GLRaV-3). Infection with each one of the three pathogens increased the levels of sucrose (ca.100\%). The differences among the effects of the individual viruses were related mainly to levels of organic acid and monosacharide. These effects were observed from the beginning of leaf expansion, suggesting a blockade in the loading of the phloem.
\end{abstract}

Apesar do grande avanço em estudos de diagnose e caracterização de vírus, muito pouco é conhecido sobre o modo de ação desses patógenos em videiras (Vitis spp.). Com o advento da técnica de análise do perfil metabólico em cromatógrafia gasosa com espectrômetro de massa (GC-MS) (Roessner et al., Plant Journal 23:131-142. 2000), surge a possibilidade de se caracterizar as alterações metabólicas exercidas por diferentes espécies virais em videiras. Esse tipo de abordagem é de extrema relevância para a caracterização do efeito que diferentes espécies ou isolados virais podem induzir no metabolismo da videira e, conseqüentemente, no seu potencial de produção. Este trabalho teve por objetivo determinar os níveis de carboidratos solúveis em folhas de videiras infetadas com Grapevine virus A (GVA), Grapevine virus $B$ (GVB), família Flexiviridae, gênero Vitivirus, ou Grapevine leafroll-associated virus 3 (GLRaV-3), família Closteroviridae, gênero Ampelovirus.

Para essa análise foram utilizados $100 \mathrm{mg}$ de folhas das cultivares LN33, Seibel e Cabernet Franc em início de expansão $\left(2-4 \mathrm{~cm}^{2}\right)$, as quais foram congeladas em nitrogênio líquido, trituradas e submetidas a uma extração alcoólica (metanol:clorofórmio:água, 12:5:3). Para a cv. LN33 (Figura 1), também foram utilizadas folhas mais expandidas $\left(25 \mathrm{~cm}^{2}\right)$. O material extraído foi submetido a um processo de derivatização com 2-N-methyl-N-(trimetylsilyl)trifluoroacetamide [MSTFA] e analisado em GC-MS. Durante o processamento de cada amostra foram adicionados $100 \mu \mathrm{g}$ de fenil- $\beta$-D-glucosídio como padrão interno. O delineamento experimental foi inteiramente casualizado e os espectros obtidos foram submetidos a uma análise de agrupamento por similaridade entre os perfis de carboidratos de folhas sadias e infetadas pelos vírus, utilizando PCA (análise de componente principal) e análise de variação canônica ao nível de significância de 5\%.

Em todas as análises pôde-se observar grande distinção entre as plantas sadias e infetadas (ex. efeitos de GVB, Figura 1). Na comparação, GVA e GVB apresentaram-se semelhantes principalmente no aumento de sacarose $(+100 \%)$ e redução de malato $(-70 \%)$, em relação as plantas sadias. O GVB também apresentou uma grande redução de succinato $(-60 \%)$ e aumento de mio-inositol ( $+30 \%$ ) (Figura 1B). O GLRaV-3 induziu aumento no teor de frutose $(+20 \%)$, galactose $(+40 \%)$, glucose $(+80 \%)$ e sacarose $(+90 \%)$ e redução de succinato $(-50 \%)$, em relação as plantas sadias. De modo geral, os vírus promoveram um acúmulo de carboidratos, o que sugere um bloqueio no carregamento do floema, tecido no qual estes vírus estam praticamente restritos. Além disso, esse trabalho salienta que os efeitos metabólicos provocados por esses vírus se manifestam em tecidos muito jovens e podem ser mais drásticos em folhas totalmente expandidas.
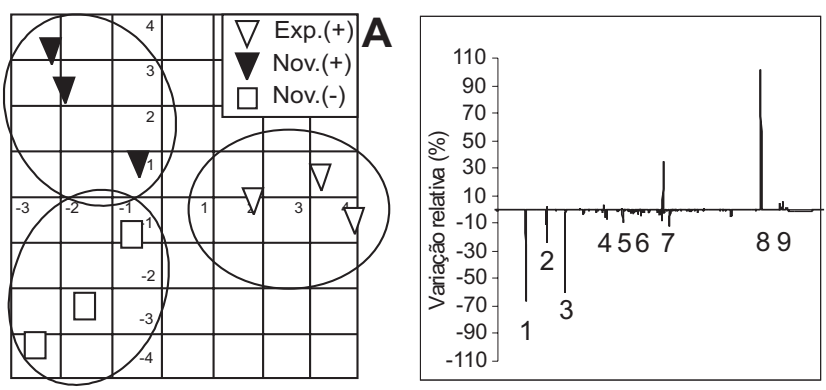

FIG. 1 - Distinção de videiras (Vitis spp.) sadias (-) e infetadas (+) pelo Grapevine virus $B(\mathbf{A})$, utilizando PCA e análise de variação canônica $(a ́=0,05)$ dos perfis metabólicos em folhas novas (nov.) e expandidas (exp.). Diferenças espectrais relativas (B) entre os perfis de folhas sadias e infetadas, salientando o efeito desta infecção viral. 1, malato; 2, metabólito desconhecido, 3, succinato; 4, D-frutose; $\mathbf{5}$, D-galactose; 6, D-glucose; 7, mio-inositol; 8, sacarose; 9, carboidratos maiores que dissacarídeos. 